\title{
PENGARUH NILAI PENDIDIKAN KARAKTER TERHADAP MOTIVASI BELAJAR PESERTA DIDIK KELAS XI SMK TEKNOLOGI \& INDUSTRI KRISTEN SALATIGA TAHUN AJARAN 2018/2019
}

\author{
Dian Yustika Rini ${ }^{1}$ Sapto Irawan ${ }^{2}$ Tritjahjo Danny Soesilo ${ }^{3}$
}

Email:

132015015@student.uksw.edu ${ }^{1}$ sapto.irawan@uksw.edu²tritjahjo.danny@uksw.edu ${ }^{3}$ Bimbingan dan Konseling FKIP-Universitas Kristen Satya Wacana Salatiga ${ }^{1,2,3}$

\begin{abstract}
Abstrak
Penelitian ini bertujuan untuk mengetahui signifikansi pengaruh nilai pendidikan karakter terhadap motivasi belajar peserta didik kelas XI SMK Teknologi\& Industri Kristen Salatiga Tahun Ajaran 2018/2019. Sampel total berjumlah 75 peserta didik (responden). Penelitian ini merupakan penelitian kuantitatif yang teknik pengukuran data untuk variabel Nilai Pendidikan Karakter menggunakan skala sikap yang dikembangkan sendiri oleh peneliti dengan mengacu pada teori dari Kemendiknas yang dikutip Wibowo, Agus (2012:43), sedangkan untuk data variabel Motivasi Belajar menggunakan skala sikap yang dikembangkan sendiri oleh peneliti dengan mengacu pada teori Sardiman (2010:83). Teknik analisis data yang digunakan dalam penelitian ini yaitu Regresi Linier Sederhana. Berdasarkan dari hasil analisis data diperoleh hasil RSquare = 0,451 yang berarti bahwa variabel nilai pendidikan karakter memberikan kontribusi pengaruh terhadap motivasi belajar peserta didik kelas XI SMK T \& I Kristen Salatiga sebesar 45,1\% dan sedangkan sisanya $54,9 \%$ dipengaruhi oleh variabel lain. Sedangkan untuk hasil Anova diperoleh hasil $\mathrm{F}_{\text {hitung }}$ sebesar 59.991 dengan sig. $=(0,000<0,05)$ dan hasil data dari Coefficients diperoleh hasil $\mathbf{t}_{\text {hitung }}>\mathbf{t}_{\text {tabel }}=7,745>5,32671$ yang dapat disimpulkan bahwa ada pengaruh yang signifikan nilai pendidikan karakter terhadap motivasi belajar peserta didik kelas XI SMK T \& I Kristen Salatiga Tahun Ajaran 2018/2019.
\end{abstract}

Kata Kunci: Nilai Pendidikan Karakter, Motivasi Belajar

\begin{abstract}
This study aims to determine the significance of the influence of the value of character education on the learning motivation of class XI students of Christian Technology \& Industry Vocational School Salatiga Academic Year 2018/2019. A total sample of 75 students (respondents). This research is a quantitative research data measurement technique for the Character Education Value variable using an attitude scale developed by the researcher with reference to the theory of the Ministry of National Education quoted by Wibowo, Agus (2012: 43), while the Motivation Learning variable data uses an attitude scale developed itself by researchers with reference to the theory of Sardiman (2010: 83). Data analysis techniques used in this study are Simple Linear Regression. Based on the results of data analysis, the results of $R$ Square $=0.451$, which means that the variable value of character education contributes to the learning motivation of students of class XI in Christian Salatiga T \& I Vocational School of $45.1 \%$ and the remaining $54.9 \%$ is influenced by other variables. As for the ANOVA results, the calculated $F$ is 59,991 with sig. $=(0,000<0,05)$ and the results of data from the Coefficients obtained results of tcount $>$ ttable $=7,745>5,32671$ which can be concluded that there is a significant effect of the value of character education on learning motivation of class XI students of Christian T \& I VOCATIONAL SCHOOL 2018/2019.
\end{abstract}

Keywords: Character Education Value; Learning Motivation

\section{PENDAHULUAN}

Bangsa Indonesia diajarkan untuk menjadi bangsa yang berkarakter melalui penerapan pendidikan karakter. Karakter sendiri lebih kuat karena berkaitan dengan sesuatu yang melekat di dalam diri setiap individu, khususnya pada para peserta didik. Karakter juga memberikan definisi mengenai suatu bangsa sebagai salah satu ciri, tanda serta pembeda antara negara satu dengan negara lainnya.

Menurut pendapat Muwafik
$(2012: 1)$ karakter sebagai suatu
pemberian arahan terhadap bagaimana
negara itu dapat menghadapi serta
melewati suatu zaman dan bisa
mengantarkan kepada derajat tertentu.
Lalu suatu bangsa yang besar merupakan
negara yang mempunyai suatu karakter
yang dapat membangun peradaban yang
besar serta dapat mempengaruhi
perkembangan di dunia.


Ketika peserta didik sedang belajar di sekolah, waktu belajar peserta didik harus dioptimalkan dengan baik, sehingga dapat membuat peningkatan pada prestasi belajar peserta didik itu sendiri. Maka dengan adanya pembentukan karakter peserta didik harus sesuai dengan tujuan yang ingin dicapai oleh pendidikan di Indonesia ini. Hal tersebut menjadi sangat penting karena mengingat bahwa peserta didik adalah generasi yang akan menjadi penerus dan penentu nasib bangsa Indonesia di kemudian hari. Apalagi karakter peserta didik sudah terbentuk sejak dini hingga sekarang. Sehingga hal tersebut akan sangat menentukan karakter bangsa di masa yang akan datang.

Disamping itu jika dalam perkembangannya tidak dikembangkan secara optimal, maka bisa berakibat pada tumbuh kembang peserta didik khususnya pada karakter yang dipunyai. Sehingga diharapkan melalui pendidikan karakter yang ada di rumah maupun sekolah yang diberikan kepada peserta didik. Bisa dapat diarahkan kepada halhal yang positif dan terhindar dari hal-hal yang negatif (tidak baik).

Menurut penelitian yang dilakukan oleh Ramadhani (2014) tentang Pengaruh Pendidikan Karakter Terhadap Motivasi Belajar Pada Siswa Kelas XI SMK Negeri 4 Klaten Tahun Pelajaran 2013/2014 menyimpulkan bahwa hasil perhitungan melalui statistik diperoleh harga sebesar 85,531 dengan signifikansi 0,000 . Sehingga $F_{\text {hitung }}>F_{\text {tabel }}$ yaitu $85,531>4,05$ dengan signifikansi sebesar 0,05 sehingga dinyatakan bahwa ada pengaruh yang signifikan antara kelompok eksperimen yang telah diberikan perlakuan dari pada kelompok kontrol yang tidak diberikan perlakuan. Jadi kesimpulan dari penelitian ini adalah pendidikan karakter memiliki pengaruh terhadap motivasi belajar siswa kelas XI SMK Negeri 4 Klaten Tahun Pelajaran 2013/2014.
Menurut hasil penelitian yang dilakukan oleh Rukaiyah (2015) tentang "Pengaruh Implementasi Pendidikan Karakter terhadap Motivasi Belajar Siswa Pada Mata Pelajaran Ekonomi Di Kelas XI SMA Negeri 1 Suwawa" Teknik analisis data yang digunakan dalam penelitian ini yaitu menggunakan Pengujian Normalitas Galat Regresi. Berdasarkan hasil perhitungan diperoleh nilai $t_{\text {hitung }}>=22,18$ dan $=1,70$. Dilihat dari hasil tersebut bahwa lebih besar dari dan berada diluar penerimaan $\mathrm{H}_{0}$. Sehingga dapat disimpulkan bahwa terdapat pengaruh antara implementasi pendidikan karakter terhadap motivasi belajar siswa.

Menurut penelitian yang dilakukan oleh Firmansyah (2017) tentang "Pengaruh Pendidikan Karakter, Lingkungan Sekolah dan Motivasi Terhadap Hasil Belajar Siswa Kelas X Tata Niaga di SMK-E Adi Karya Kabupaten Pesisir Selatan", menunjukkan bahwa: Pendidikan Karakter berpengaruh signifikan terhadap Motivasi Belajar Siswa kelas X Tata Niaga di SMK-E Adi Karya Kabupaten Pesisir Selatan, dimana diperoleh nilai koefisien jalur 0,410 dan $t_{\text {hitung }} 3,774>t_{\text {tabel }} 1,996$.

Menurut penelitian yang dilakukan oleh Nisa (2017) tentang "Pengaruh Pendidikan Karakter terhadap Motivasi Belajar Siswa kelas III di MI MA'ARIF Ngrupit Jenangan Ponorogo Tahun Ajaran 2016/2017" Penelitian ini menggunakan metode kuantitatif untuk mengetahui seberapa besar pengaruh pendidikan karakter terhadap motivasi belajar pada siswa kelas III di MI MA'ARIF Ngrupit Jenangan Ponorogo. Teknik analisis data yang digunakan dalam penelitian ini yaitu menggunakan Pengujian Regresi Linier Sederhana.Berdasarkan hasil perhitungan diperoleh nilai $t_{\text {hitung }}>=12,324$ dan $t_{\text {tabel }}=$ 10,652. Dilihat dari hasil tersebut bahwa $\mathrm{t}_{\text {hitung }}$ lebih besar dari $\mathrm{t}$ tabel dan berada diluar penerimaan $\mathrm{H}_{0}$. Sehingga dapat 
ditarik kesimpulan bahwa terdapat pengaruh antara pendidikan karakter terhadap motivasi belajar siswa.

Menurut penelitian yang dilakukan oleh Nafi'ah (2016) tentang "Pengaruh Persepsi Tenatang Pendidikan Karakter Terhadap Motivasi Belajar Biologi Peserta Didik Kelas X Madrasah Aliyah Darul Ulum Kalinyamatan Jepara menyimpulkan bahwa dengan persamaan garis regresinya adalah $\hat{\mathrm{Y}}=27,206+$ $0,061 X$. Hasil analisis varians regresinya diperoleh nilai Freg sebesar 70, 32 yang dikonsultasikan dengan $\mathrm{F}_{\text {tabel, }}$, pada taraf signifikan 5\% sebesar 3, 94 karena harga $\mathrm{F}_{\text {reg }}>\mathrm{F}_{\text {tabel, }}$ maka persamaan garis regresi tersebut menunjukkan signifikan. Hal ini berarti Hipotesis kerja $\left(\mathrm{H}_{\mathrm{a}}\right)$ yang menyatakan "Ada pengaruh persepsi tentang pendidikan karakter terhadap motivasi belajar biologi" diterima. Nilai besarnya pengaruh persepsi tentang pendidikan karakter terhadap motivasi belajar biologi di Madrasah Aliyah Darul Ulum Kalinyamatan Jepara sebesar $40,8 \%$.

Menurut hasil penelitian yang dilakukan oleh Winarsih (2012) tentang Pengaruh Pendidikan Karakter Siswa, Kepribadian Siswa Terhadap Motivasi Belajar Pada Mata Pelajaran Ekonomi Siswa Kelas XI IPS SMA Negeri 9 Pontianak Tahun Pelajaran 2011/2012 menyimpulkan bahwa penelitian ini $\mathrm{H}_{\mathrm{a}}$ ditolak dan $\mathrm{H}_{0}$ diterima. Hal ini dibuktikan dengan nilai $\mathrm{R}$ square masing-masing variabel $\mathrm{X}_{1}=0,002(2 \%)$, $\mathrm{X}_{2}=0,000(0 \%)$, dan $\mathrm{X}_{3}=0,053(5,3 \%)$. Pendidikan Karakter tidak memiliki pengaruh yang signifikan terhadap motivasi belajar, karena hanya memiliki pengaruh sebesar 8\% ( $\mathrm{R}$ square 0,080). Artinya pendidikan karakter tidak memberikan pengaruh yang besar terhadap motivasi belajar. Namun faktorfaktor lain yang mempengaruhi motivasi belajar sebanyak $92 \%$ dipengaruhi oleh tingkat kecerdasan siswa, perhatian, minat, bakat dan lingkungan. Hasil penelitian ini direkomendasikan kepada siswa agar lebih meningkatkan motivasi belajarnya di sekolah maupun di rumah.

Berdasarkan hasil wawancara dengan Guru Bimbingan Konseling atau Konselor di SMK Teknologi \& Industri Kristen Salatiga. Ditemukan bahwa setiap peserta didik mempunyai karakter yang berbeda-beda, hal ini dikarenakan kebiasaan-kebiasaan yang dilakukan semenjak peserta didik ini masih kecil sampai sekarang dengan dipengaruhi oleh faktor lingkungan keluarga, masyarakat, pergaulan, dan bahkan media elektronik. Karakter siswa yang berbeda-beda ini tentunya memberikan kerja ekstra bagi guru untuk terus melaksanakan pendidikan karakter ini secara konsistendan di dalam pembangunan karakter di SMK Teknologi \& Industri Kristen Salatiga yang berhubungan dengan etos kerja dan karir. Pembentukan karakter peserta didik di SMK Teknologi \& Industri Kristen Salatiga dengan bekerja keras, cerdas, tuntas, dan ikhlas untuk mencapai kesuksesan serta pilihan tersebut dapat dipertanggungjawabkan, sehingga melalui praktek kerja yang ada di SMK Teknologi \& Industri Kristen Salatiga bisa menumbuhkan suatu etos kerja, keinginan untuk maju dan sukses.

Menurut penjelasan dari guru mata pelajaran Matematika, PKn dan Kewirausahaan yang mengajar di SMK Teknologi \& Industri Kristen Salatiga, pada motivasi belajar peserta didik di SMK ini termasuk sedang hal ini nampak pada saat peserta didik mengikuti pelajaran di kelas para peserta didik sering mengobrol dengan teman sebangku atau teman yang lain, sering tidak memperhatikan penjelasan materi yang disampaikan oleh para guru, sering ijin untuk keluar kelas selama pelajaran berlangsung. Hal ini membuat peserta didik kurang fokus dalam mengikuti pembelajaran di kelas, dengan begitu bisa dikatakan motivasi belajarnya perlu untuk dituntun, didukung dan dikenalkan lagi. 
Motivasi yang paling prioritas itu adalah motivasi belajar, apalagi dalam kehidupan ini ada proses belajar, tapi peserta didik ini belum tahu dan juga harus dikenalkan. Jadi dengan begitu ada pengaruh antara nilai pendidikan karakter terhadap motivasi belajar siswa di SMK T \& I Kristen Salatiga.

Berdasarkan uraian-uraian permasalahan yang telah di paparkan sebelumnya, menggugah peneliti untuk melakukan penelitian tentang "Pengaruh Nilai Pendidikan Karakter Terhadap Motivasi Belajar Peserta Didik Kelas XI SMK Teknologi \& Industri Kristen Salatiga Tahun Ajaran 2018/2019”.

\section{KAJIAN PUSTAKA Motivasi Belajar}

Menurut pendapat Nadlir, dkk (dalam Prawira., 2014:313) motivasi adalah tenaga-tenang (forces) yang membangkitkan dan mengarahkan kelakuan individu. Motivasi dapat juga dikatakan sebagai serangkaian usaha untuk menyediakan kondisi-kondisi tertentu, sehingga seseorang mau dan ingin melakukan sesuatu, dan bila individu tidak suka, maka akan berusaha untuk meniadakan atau mengelakkan perasaan tidak suka tersebut. Jadi motivasi itu dapat dirangsang oleh faktor dari luar dan motivasi itu adalah tumbuh di dalam diri seseorang (Sardiman., 2010:75).

Belajar merupakan suatu proses yang dapat menimbulkan atau mengubah perilaku melalui pengalaman atau latihan (Djamarah., 2008:12). Sama halnya menurut Mulyati (dalam Djamarah., 2008:13) belajar merupakan suatu usaha sadar dari individu, untuk mencapai tujuan peningkatan diri atau perubahan diri, melalui latihan-latihan, pengulangan-pengulangan dan perubahan terjadi bukan karena peristiwa kebetulan.

Motivasi belajar merupakan semua upaya yang ada di dalam diri peserta didik yang menyebabkan proses dalam aktivitas belajar, yang memberi jaminan pada proses belajar dan yang memberikan arahan pada aktivitas belajar berlangsung, dengan begitu tujuan yang dikehendaki oleh subyek belajar tercapai (Dimyati dan Mudjiono., 2013:83). Sardiman (2010:75) juga berpendapat bahwa motivasi belajar adalah merupakan faktor psikis yang bersifat non-intelektual. Peranannya yaitu dalam hal penumbuhan gairah, merasa senang dan semangat untuk belajar.

Menurut Sardiman (2010:83), Motivasi yang ada pada diri seseorang, memang sukar untuk diketahui dan diakui, namun demikian dapat diinterpretasikan dari bentuk tingkah laku dengan ciri-ciri sebagai berikut:

1) Tekun dalam menghadapi tugas, dapat bekerja dengan terus menerus dalam jangka waktu lama, tidak pernah berhenti sebelum selesai.

2) Ulet dalam menghadapi kesulitan (tidak lekas putus asa). Tidak memerlukan dorongan dari luar untuk berprestasi sebaik mungkin (tidak mudah putus asa dengan prestasi yang dicapainya).

3) Menunjukkan minat belajar dan terhadap macam-macam masalah untuk orang dewasa (misalnya masalah pembangunan, agama, politik, ekonomi, keadilan, dan sebagainya).

4) Mandiri dalam belajar.

5) Cepat bosan terhadap tugas-tugas rutin (hal-hal yang bersifat mekanis, berulang-ulang begitu saja sehingga kurang kreatif).

6) Memiliki harapan dan cita-cita masa depan serta kemampuan belajar,senang mencari dan memecahkan masalah soal-soal.

\section{Nilai Pendidikan Karakter}

Gordon Allport (dalam Zubaidi., 2011:45) Nilai merupakan suatu keyakinan yang dapat membuat seseorang melakukan tindakan berdasarkan pilihannya. Sama halnya 
dengan penjelasan menurut Mulyana (Rukaiyah., 2015:12) Nilai adalah suatu keyakinan dan rujukan untuk menentukan sebuah pilihan.

Menurut Menanti (dalam Utami., 2013:19) Pendidikan Karakter merupakan sesuatu yang berpengaruh positif terhadap motivasi belajar peserta didik. Hal ini dikarenakan pendidikan karakter mengupayakan untuk membangun nilainilai dan norma-norma yang menampilkan suasana akademik, yaitu suasana yang menampilkan perilaku sesuai nilai-nilai dan kaidah-kaidah ilmiah dalam upaya memperoleh dan membangun pengetahuan dan mencari kebenaran.Mendiknas (dalam Wibowo., 2012:35) pendidikan karakter adalah pendidikan yang mengembangkan nilainilai karakter bangsa pada diri peserta didik, sehingga mereka memiliki nilai dan karakter dirinya, menjalankan nilainilai tersebut di dalam kehidupan peserta didik, sebagai anggota dalam kehidupan bermasyarakat, dan menjadi penduduk di masyarakat yang bereligius, cinta tanah air, produktif dan kreatif sehingga bermanfaat bagi bangsa dan negara.

Jadi, dapat disimpulkan bahwa nilai pendidikan karakter adalah suatu keyakinan yang dimiliki oleh peserta didik untuk dapat berpikir, bersikap, dan bertindak yang dapat diaplikasikan dalam kesehariannya, serta bisa memberikan kontribusi yang baik terhadap lingkungan sekitar.

\section{METODE PENELITIAN}

Penelitian ini menggunakan jenis penelitian kuantitatif. Populasi dalam penelitian ini adalah seluruh peserta didik kelas XI SMK Teknologi \& Industri Kristen Salatiga yang berjumlah 75 peserta didik.Sampel yang digunakan dalam penelitian ini adalah dengan menggunakan total sampling, Penggunaan teknik sampling total dilakukan dengan cara mengambil subjek berdasarkan jumlah keseluruhan populasi sehingga yang menjadi sampel atau subjek penelitian adalah 75 peserta didik kelas XI SMK T \& I Kristen Salatiga.

Dalam penelitian ini terdapat 2 variabel yaitu variabel bebas (X) dan variabel terikat (Y). Menurut Soesilo (2018:35) variabel independen (bebas) merupakan suatu kondisi atau nilai yang jika muncul maka akan mengubah kondisi atau nilai yang lain. Variabel independen (bebas) dalam penelitian ini yaitu Nilai Pendidikan Karakter (X).Menurut Soesilo (2018:36) bahwa variabel dependen (terikat) ini adalah suatu kondisi atau nilai yang muncul sebagai akibat adanya variabel bebas. Variabel dependen (terikat) dalam penelitian ini yaitu Motivasi Belajar (Y).

Pada Uji Coba Instrumen Penelitian menggunakan validitas dan reliabilitas. Azwar (2013:108) pernyataan dinyatakan valid jika corrected item-total correlation $\alpha>0,30$. Untuk mengetahui reliabilitas variabel digunakan Alpha Cronbach minimal 0,70 semakin dekat koefisien keandalan dengan 1,0 maka semakin baik (Arikunto., 2010:111).

Hasil uji validitas diperoleh hasil bahwa nilai pendidikan karakter $(\mathrm{X})$ yang valid ada 55 item. Item-item pernyataan tersebut mempunyai koefisien corrected item to total correlation yang terendah sebesar $(0,303)$ dan tertinggi sebesar $(0,733)$ dengan reliabilitas sebesar 0,955 yang berkategori sangat tinggi. Motivasi Belajar (Y) yang valid ada 48 item. Itemitem pernyataan tersebut mempunyai koefisien corrected item to total correlation yang terendah sebesar0,312 dan yang tertinggi sebesar 0,741 dengan reliabilitas sebesar 0,946 yang berkategori sangat tinggi.

\section{HASIL PENELITIAN}

\section{Analisis Deskripsi Motivasi Belajar}

Berdasarkan data sebaran frekuensi padavariabel motivasi belajar yang dimiliki oleh peserta didik kelas XI T \& I Kristen Salatiga sebagian besar berada dalam kategori tinggi dengan persentase sebesar $70,67 \%$. 


\section{Analisis Deskripsi Nilai Pendidikan Karakter}

Dengan demikian didapatkan bahwa berdasarkan data sebaran frekuensi di variabel nilai pendidikan karakter yang dimiliki oleh peserta didik kelas XI SMK T \& I Kristen Salatiga tergolong pada kategori sedang dengan persentase 11nilai-nilai karakter sebagai berikut: Nilai kejujuran yang dimiliki oleh peserta didik kelas XI tergolong pada kategori sedang dengan persentase sebesar 46,67\%.Nilai displin yang dimiliki oleh peserta didik kelas XI tergolong pada kategori sedang dengan persentase sebesar $58,67 \%$.Nilai kerja sama yang dimiliki oleh peserta didik kelas XI tergolong pada kategori tinggi dengan persentase sebesar 53,33\%.Nilai tanggungjawab yang dimiliki oleh peserta didik kelas XI tergolong pada kategori sedang dengan persentase sebesar 61,33\%.Nilai komunikatifyang dimiliki oleh peserta didik kelas XI tergolong pada kategori sedang dengan persentase sebesar 66,67\%.Nilai kreatif yang dimiliki oleh peserta didik kelas XI tergolong pada kategori sedang dengan persentase sebesar 46,67\%.Nilai mandiri yang dimiliki oleh peserta didik kelas XI tergolong pada kategori sedang dengan persentase sebesar $48 \%$.Nilai rasa ingin tahu yang dimiliki oleh peserta didik kelas XI tergolong pada kategori tinggi dengan persentase sebesar 60\%.Nilai menghargai prestasi yang dimiliki oleh peserta didik kelas XI tergolong pada kategori sedang dengan persentase sebesar $40 \%$.Nilai gemar membaca yang dimiliki oleh peserta didik kelas XI tergolong pada kategori sedang dengan persentase sebesar $42,67 \%$.Nilai peduli sosial yang dimiliki oleh peserta didik kelas XI tergolong pada kategori sedang dengan persentase sebesar 73,33\%,

\section{Analisis Regresi Linier Sederhana}

Untuk mengetahui hasil analisis

Regresi Variabel Nilai Pendidikan
Karakter terhadap Motivasi Belajar, dapat dilihat pada tabel 1, sebagai berikut:

Tabel 1. Hasil Analisis Regresi Variabel Nilai Pendidikan Karakter terhadap Motivasi Belajar

Model Summary

\begin{tabular}{lccccc}
\hline & & $\begin{array}{c}\mathrm{R} \\
\text { Model }\end{array}$ & $\mathrm{R}$ & $\begin{array}{c}\text { Sdjusted } \\
\text { Square }\end{array}$ & $\begin{array}{c}\text { Std. Error } \\
\text { of the }\end{array}$ \\
\hline 1 & $.672^{\mathrm{a}}$ & .451 & .444 & 12.20931 \\
\hline a. & \multicolumn{3}{c}{ Predictors: } & & (Constant), \\
NilaiPendidikanKarakter & & &
\end{tabular}

Pada bagian tabel 1 ini ditampilkan bahwa $R=0,672$ artinya koefisiennya sebesar 0,672. Lalu pada $R$ Square = 0,451 menunjukkan angka koefisien determinasinya $\left(\mathrm{R}^{2}\right)$. Artinya variansi dalam Nilai Pendidikan Karakter memiliki pengaruh atau kontribusi terhadap Motivasi Belajar sebesar 45,1\% dan sisanya dipengaruhi dari variabel lain. Atau besarnya pengaruhNilai Pendidikan Karakter terhadap Motivasi Belajar adalah $45,1 \%$, sisanya $(54,9 \%)$ berasal dari variabel lain.Kemudian pada Adjusted $R$ Square $=0,444$. Ukuran ini maknanya sama dengan $R$ Square, hanya saja Adjusted $R$ Square ini nilainya lebih stabil karena sudah disesuaikan dengan variabel bebasnya. Pada Standard Error of the Estimate = 12,20931 yang menunjukkan ukuran tingkat kesalahan dalam melakukan prediksi terhadap variabel terikat.

Untuk mengetahui hasil Uji Linieritas Anova, dapat dilihat pada tabel 2, sebagai berikut:

Tabel 2. Hasil Uji Linieritas Anova

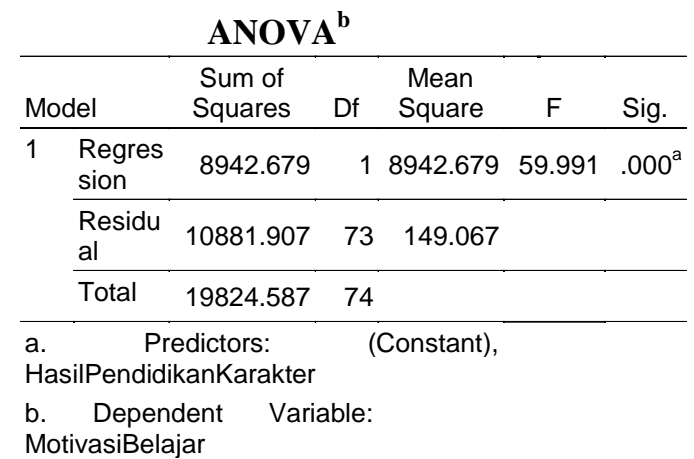

Pada tabel 2 bagian uji ANOVA atau $F_{\text {test }}$ ini menampilkan hasil pengujian 
koefisien determinasi. Hasil pengujian tersebut ditemukan harga $\mathrm{F}$ hitung sebesar 59,991 dengan sig. $=0,000$. Oleh karena itu nilai sig. $<0,05$ maka $H_{o}(\rho=$ 0 ) ditolak yang artinya Hasil Pendidikan Karakter memiliki pengaruh yang signifikan terhadap Motivasi Belajar.

Untuk mengetahui hasil Regresi Linier Sederhana, dapat dilihat pada tabel 3, sebagai berikut:

Tabel 3. Hasil Regresi Linier Sederhana

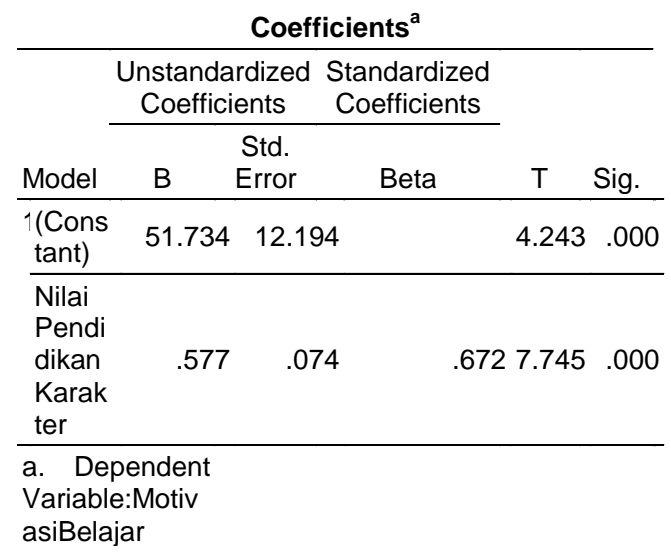

Pada bagian tabel 3 yang menampilkan persamaan garis regresi dan pengujiannya. Persamaan garis regresi dapat diperoleh dari kolom Unstandardized Coefficients (B). Dengan demikian persamaan garis regresinya adalah: $\mathrm{Y}^{\prime}=51,734+0,577$ $\mathrm{X}$. Kemudian untuk menguji koefisien garisnya dapat dilihat pada kolom $\mathbf{t}$ dan sig. Hasil pengujian ditemukan nilai $\mathbf{t}$ hitung sebesar 7,745 dan $\mathbf{t}_{\text {tabel }}$ sebesar 5,32671 dengan sig. $=0,000$. Jadi karena nilai sig. $<0,05$ maka Ho $(\beta=0)$ ditolak yang artinya Nilai Pendidikan Karakter berpengaruh Positif terhadap Motivasi Belajar.

\section{PEMBAHASAN}

Berdasarkan data yang sudah didapatkan dari hasil analisis dengan menggunakan teknik analisis regresi linier sederhana dengan bantuan SPSS for Windows Release 22.0. menunjuk-kan bahwa hasil signifikansinya diperoleh sebesar $0,000<0,05$ yang berarti bahwa ada pengaruh yang signifikan Nilai Pendidikan Karakter terhadap Motivasi
Belajar pada Peserta Didik kelas XI SMK T \& I Kristen Salatiga Tahun Pelajaran 2018/2019, dengan persamaan garis regresinya adalah: $\mathrm{Y}^{\prime}=51.734+0,577 \mathrm{X}$ dan $F_{\text {hitung sebesar } 59.991 \text { dengan sig. = }}$ 0,000 . Oleh karena itu nilai sig. $<0,05$ maka $H_{o}(\rho=0)$ ditolak yang artinya Nilai Pendidikan Karakter memiliki pengaruh yang signifikan terhadap Motivasi Belajar. Selain itu hipotesis diterima jika $\mathbf{t}_{\text {hitung }}>\mathbf{t}_{\text {tabel }}=7,745$ $>5,32671$ yang artinya ada pengaruh yang signifikan antara keduanya. Nilai pendidikan karakter memberikan kontribusi pengaruh terhadap motivasi belajar peserta didik kelas XI SMK T \& I Kristen Salatiga sebesar 45,1 \%dan sedangkan sisanya sebesar 54,9\% dipengaruhi oleh variabel lain.

Adapun beberapa variabel lain yang dapat mempengaruhi terhadap Motivasi Belajar peserta didik, seperti yang dikemukakan oleh Dimyati dan Mudjiono (2013:97-100), beberapa faktor yang mempengaruhi motivasi belajar seperti: cita-cita atau aspirasi siswa, kemampuan belajar siswa, kondisi siswa, kondisi lingkungan siswa, unsur-unsur dinamis dalam belajar dan pembelajaran, upaya guru membelajarkan siswa. Kemudian menurut Sardiman (2010:90) bahwa pengaruh dari luar individu atau karena adanya ajakan, suruhan atau paksaan dari orang lain. Sehingga dengan adanya kondisi demikian, akhirnya peserta didik mau melakukan sesuatu untuk belajar, sebagai contoh: seseorang mau belajar karena disuruh oleh orang tuanya agar mendapat peringkat dikelasnya.

$$
\text { Menurut hasil penelitian }
$$

(Ramadhani., 2014:8) menyatakan bahwa upaya pihak sekolah (guru) yang perlu dilakukan untuk meningkatkan motivasi belajar peserta didik terkait hasil penelitian tesebut diantaranya: guru memberikan contoh keteladanan pada peserta didik, sehingga ketika guru memberikan nasehat, bimbingan, arahan dan support (dukungan) bagi peserta 
didik untuk belajar dan betapa pentingnya pendidikan; guru memberikan pujian yang wajar pada setiap keberhasilan peserta didik untuk memberikan penghargaan atas jerih payahnya dalam belajar; guru menciptakan suasana belajar di kelas yang menyenangkan agar dapat mengaktifkan kemampuan siswa dalam memperoleh pendidikannya sekaligus memotivasi peserta didik dalam belajar dan guru menggunakan variasi metode penyajian pembelajaran yang menarik, sehingga akan membangkitkan rasa ingin tahu peserta didik dan termotivasi dalam belajar.

Jadi, nilai-nilai pendidikan karakter yang relevan dengan motivasi belajar yang dimiliki peserta didik kelas XI SMK $\mathrm{T} \&$ I Kristen Salatiga diantaranya ada nilai kejujuran, nilai disiplin, nilai kerja keras, nilai tanggungjawab, nilai komunikatif, nilai kreatif, nilai mandiri, nilai rasa ingin tahu, nilai menghargai prestasi, nilai gemar membaca dan nilai peduli sosial. Yang menghasilkan pengaruh signifikan antar dua variabel tersebut.

\section{PENUTUP}

\section{Simpulan}

Berdasarkan dari penelitian yang sudah dilakukan pada peserta didik kelas XI SMK T \& I Kristen Salatiga Tahun Pelajaran 2018/2019, maka dapat ditarik kesimpulan bahwa:"Ada pengaruh yang signifikan Nilai Pendidikan Karakter terhadap Motivasi Belajar peserta didik kelas XI SMK T \& I Kristen Salatiga Tahun Ajaran 2018/2019, denganhasil Anova diperoleh hasil $F_{\text {hitung }}$ sebesar 59.991 dengan sig. $=(0,000<0,05)$ dan hasil data dari Coefficients diperoleh hasil $\mathbf{t}_{\text {hitung }}>\mathbf{t}_{\text {tabel }}=7,745>5,32671$.

\section{Saran}

Kepada Guru BK (konselor), diharapkan bisa memberikan layanan yang layanan Bimbingan dan Konseling yang lebih kreatif dan bervariatif, agar peserta didik bisa mengembangkan diri khususnya pada pendidikan karakter dan motivasi belajar pada peserta didik tersebut.

Berdasarkan hasil penelitian ini, diharapkan bisa menjadi suatu bahan masukan bagi pihak sekolah untuk dapat memberikan dan meningkatkan pemahaman mengenai gambaran pendidikan karakter dan motivasi belajar kepada para peserta didik agar dapat memahami dan bisa menerapkan hal tersebut di dalam kehidupannya baik di sekolah, rumah maupun lingkungan masyarakat.

Bagi peneliti selanjutnya yang hendak melanjutkan penelitian ini kembali mengenai pengaruh nilai pendidikan karakter terhadap motivasi belajar, diharapkan dalam pengambilan sampel dan populasi agar lebih di perluas, sehingga hasil yang akan didapatkan menjadi lebih variasi dan lengkap. Selain itu, peneliti dapat meneliti variabel lain yang dapat mempengaruhi motivasi belajar yaitu pada kemampuan belajar siswa, kondisi siswa, kondisi lingkungan siswa, unsur-unsur dinamis dalam belajar dan mengajar maupun upaya guru membelajarkan siswa.

\section{DAFTAR PUSTAKA}

Arikunto, Suharsami. 2010. Manajemen Penelitian. Jakarta: PT. Rineka Putra.

Azwar, Saifuddin. 2013. Skala Psikologi. Yogyakarta: Pustaka Pelajar.

Dimyati \& Mudjiono. 2013. Belajar dan Pembelajaran. Jakarta: Rineka Cipta.

Djamarah, Syaiful Bahri. 2008.Psikologi Belajar. Jakarta: Rineka Cipta.

Firmansyah, Debi. 2017.Pengaruh Pendidikan Karakter,

Lingkungan Sekolah dan Motivasi Terhadap Hasil Belajar Siswa Kelas X Tata Niaga di SMK-E Adi Karya Kabupaten Pesisir Selatan. Jurnal Program Studi Pendidikan Ekonomi: (STKIP) PGRI Sumatera Barat. Vol. 4. No. 2. 
(diunduh tanggal 22 Mei 2018

Pukul 14.30 WIB).

Muwafik, Saleh. 2012. Membangun

Karakter dengan Hati Nurani. Jakarta: Erlangga.

Nafi'ah, Miftahun. 2016.Pengaruh Persepsi Tentang Pendidikan

Karakter Terhadap Motivasi

Belajar Biologi Peserta Didik

Kelas X Madrasah Aliyah Daru

Ulum Kalinyamatan Jepara.

Jurnal Pendidikan Biologi

Fakultas Sains dan Matematika:

Universitas Islam Negeri

Walisongo. Vol. 9. No. 1.

(diunduh tanggal 22 Mei 2018

Pukul 15.15 WIB).

Nisa, Luthfiyatun. 2017. Pengaruh

Pendidikan Karakter terhadap

Motivasi Belajar Siswa Kelas III

di MI MA'ARIF Ngrupit

Jenangan PonorogoTahun

Ajaran 2016/2017. Jurnal

Pendidikan Guru Madrasah

Ibtidaiyah: IAIN Ponorogo.

Vol.2. No.1. (diunduh tanggal

23 Mei 2018 Pukul 10.30 WIB).

Prawira, Purwa Atmaja. 2014. Psikologi

Pendidikan dalam Perspektif

Baru. Yogyakarta: Ar-Ruzz Media.

Ramadhani, Annisa. 2014. Pengaruh Pendidikan Karakter Terhadap Motivasi Belajar Pada Siswa Kelas XI SMK Negeri 4 Klaten Tahun Pelajaran 2013/2014. Jurnal FKIP UNS. Vol. 1. No. 2.(diunduh tanggal 23 Mei 2018 Pukul 15.15 WIB).

Rukaiyah, Siti. 2015.Pengaruh Implementasi Pendidikan Karakter terhadap Motivasi Belajar Siswa Pada Mata Pelajaran Ekonomi Di Kelas XI SMA Negeri 1 Suwawa. Jurnal Pendidikan Ekonomi Fakultas Ekonomi dan Bisnis: Universitas Negeri Gorontalo. Vol. 3. No. 1. (diunduh tanggal 23 Mei 2018 Pukul 15.40 WIB)

Sardiman. 2010. Interaksi dan Motivasi Belajar Mengajar. Jakarta: Raja Grafindo Persada.

Soesilo, Tritjahjo Danny. 2018. Penelitian Inferensial dalam Bidang Pendidikan. Salatiga: Satya Wacana University Press.

Sugiyono. 2010. Metode Penelitian Pendidikan. Bandung: Alfabet.

Utami, Khabibah. 2013. Pengaruh Pendidikan Karakter dan Sikap Guru dalam Kegiatan Belajar Mengajar di dalam Kelas Terhadap Prestasi Belajar Produktif Akuntasi Siswa kelas X Program Keahlian Akuntansi SMK Negeri 1 Salatiga Kota Salatiga Tahun Pelajaran 2012/2013.Jurnal Ekonomi \& Pendidikan: UNNES. Vol. 7. No. 1. (diunduh tanggal $25 \mathrm{Mei}$ 2018 Pukul 10.20 WIB).

Wibowo, Agus. 2012. Pendidikan Karakter (Strategi Mem-bangun Karakter Bangsa

Berperadaban). Yogyakarta: Pustaka Pelajar.

Winarsih, Wiwin. 2012.Pengaruh Pendidikan Karakter Siswa, Kepribadian Siswa Terhadap Motivasi Belajar Pada Mata Pelajaran Ekonomi Siswa Kelas XI IPS SMA Negeri 9 Pontianak Tahun Pelajaran 2011/2012. Jurnal Pendidikan Ekonomi FKIP: Universitas Tanjungpura. Vol. 2. No. 2. (diunduh tanggal 12 September 2018 Pukul 12.35 $W I B)$.

Zubaidi. 2011. Desain Pendidikan Karakter. Jakarta: Kencana Prenada Media Group. 